\section{Australia losing more brains}

\section{Sydney}

Australia's brain drain is intensifying, according to a new survey by a senior lecturer in mathematics at the Australian National University in Canberra. An entire generation of the country's most outstanding mathematicains seems likely to be lost to overseas institutions.

The survey, carried out by John Hutchinson, tracked 62 students who graduated with first-class honours in mathematics during 1970-87. Thirty-five of them are involved in research and development and thirty-two have received doctorates. But none is working in Australian industry and more than half have gone overseas, mostly to the United States.

Recently, the percentage going overseas has increased. Seventy-five per cent

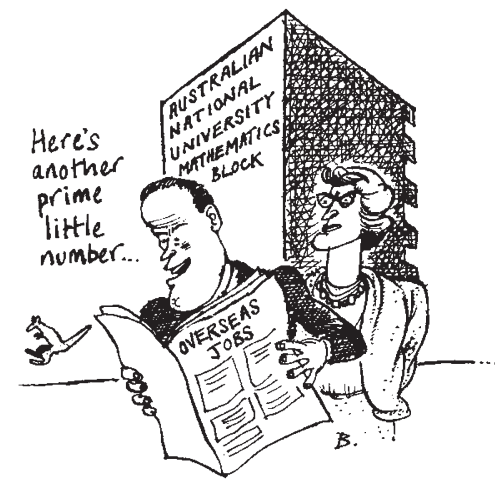

of those who graduated in 1970-75 are still in Australia. But only 35 per cent of those who graduated in the following five years have remained at home. The report concludes that while improved salaries would help to retain and attract scientists, the major consideration is a stimulating and stable research environment.

According to Jim Peacock, chief of the Division of Plant Industry within the Commonwealth Scientific and Industrial Research Organization (CSIRO), it costs $\mathrm{A} \$ 500,000$ to train a scientist to the end of a postdoctoral fellowship. "At the end of this period they are at their most productive for Australia and we should be doing all we can to keep them", he said.

Scientists who have remained in Australia are becoming increasingly angry about their plight. The Prime Minister, Bob Hawke, was heckled by 700 scientists at the recent opening of the new National Science and Technology Centre in Canberra. The scientists were protesting at continuing cuts in government support for scientific research. Hawke attempted to calm the crowd by promising increases in funds for scientific and technological research. A committee of senior civil servants has been set up to report on the need for further funds.

\title{
NSF providing support to get new centres off the ground
}

Washington

THE US National Science Foundation (NSF) last week announced that it will spend $\$ 25$ million in fiscal year 1989 on eleven Science and Technology Centers intended to foster cooperative research among university, industrial and national laboratories. The intended benefit, says NSF director Eric Bloch, is "a much shorter time-span between actual discovery and utilization".

Although the centres are intended to increase the ability of the United States to compete in world markets, it proved impossible to find funds for them last year. This year, Congress turned down a request for a separate five-year \$150-million appropriation for the centres but gave NSF enough funds for the first year of operations.

Competition for the centres was severe. NSF received 323 proposals and employed more than 1,000 reviewers to help whittle them down to a short list of 48 finalists. Site visits from a 23 -member multidisciplinary panel resulted in the choice of 11 centres for awards ranging from $\$ 900,000$ to $\$ 4$ million.

The centres are university based, and with one exception focus on topics where basic research seems likely to reap financial dividends. The exception is the University of California at Berkeley which will receive $\$ 1.8$ million for a Center for Particle Astrophysics under the direction

of Bernard Sadoulet. In collaboration with other California universities and the Lawrence Berkeley Laboratory, the centre will search for the 'essence' of the dark matter, known only by its gravitational effects, that makes up 90 per cent of the mass in the Universe.

The remaining centres and their budgets are: University of California at Santa Barbara Center for Quantized Electronic Structures ( $\$ 2.1$ million) 1 California Institute of Technology Center for the Development of an Integrated Protein and Nucleic Acid Technology (\$3.0 million) University of Illinois at Champaign-Urbana Center for HighTemperature Superconductivity $\quad(\$ 4.2$ million) - Michigan State University Center in Microbial Ecology $(\$ 1.1 \mathrm{mil}-$ lion) - Northwestern University Center for Advanced Cement-Based Materials (\$1.7 million) University of Oklahoma Center for Analysis and Prediction of Storms (\$0.9 million) - Rice University Center for Research on Parallel Computation (\$4.1 million) University of Rochester Center for Photoinduced Charge Transfer (\$1.6 million) $\square$ Rutgers University Center for Discrete Mathematics and Theoretical Computer Science (\$1.8 million) - Virginia Polytechnic Institute and State University Center for High-Performance Polymeric Adhesives and Composites ( $\$ 2.1$ million).

Alun Anderson

\section{South African doctor sacked "inexplicably"}

Oxford

A MAJOR controversy has erupted in South African medical circles over the transfer of the chief superintendent of Cape Town's Groote Schuur Hospital, Dr Jocelyn KaneBerman, after she was quoted in a weekend newspaper as having named Nelson Mandela as her choice as prime minister in a South African cabinet selected on merit.

Kane-Berman was transferred from her post at the end of last month to be regional medical superintendent for the Western Cape. The administrator of the Cape Province, Mr Gene Louw, issued a statement on 9 December confirming that KaneBerman's transfer was a disciplinary measure, and refusing to reinstate her. He justified this decision on the grounds that Kane-Berman's comments were "closely linked to radical politics". He added: "In the present political climate it is top priority for all provincial officials, in the execution of their responsibilities, to desist at all costs from personal political involvement or statements which may harm the provincial government service."
Condemnation of Kane-Berman's transfer has been widespread. Dr Stuart Saunders, vice-chancellor of UCT and former head of its department of medicine, said that he was "dismayed" by the administrator's decision, and called for the reinstatement of Dr Kane-Berman. The Public Servants League described her removal as "inexplicable considering the reasons so far". Even the federal council of the conservative Medical Association of South Africa (MASA) has asked for her reinstatement. Both MASA and UCT have promised to support Kane-Berman if she decides to appeal to the courts to overturn the administrator's decision.

Perhaps the most pertinent comment came from Dr Marius Bernard, the Progressive Federal Party's spokesman on health. He criticized the administrator for claiming that Kane-Berman had brought politics into the health services, adding: "The government has politicized the health service and administers National Party policy daily, as can be seen in its segregated hospitals".
Michael Cherry 